\title{
Analysis Characteristics and Performance Intersections Signal Rawa Panjang Related to Odd-Even Policy on West Bekasi Toll Door
}

\author{
Widodo Budi Dermawan dan Ahmad Chalimin \\ Faculty of Engineering, University of Mercu Buana Bekasi, Indonesia \\ wbdermawan@gmail.com, Chalinda.collection@gmail.com
}

\begin{abstract}
The application of Odd-Even policies on the Bekasi West Toll door to unravel the volume of traffic on the JakartaCikampek Toll Road, with the hope that motorists can use public transportation provided by the government so that they can also decipher the volume of traffic flow within the city. Bekasi itself, especially in the main intersections in the city. The method used for collecting data is primary data and secondary data. Primary data is data taken through direct observation in the real field. Primary data consists of vehicle volume data and actual conditions of intersections such as side barriers. Secondary data is data on road size, road conditions and completeness, and population. Furthermore, for this study, the calculation method used the reference available in the 1997 Indonesian Road Capacity Manual (MKJI). From the results of the analysis, the performance of long swamp signal intersections at maximum currents has Level Of Service (LOS) or level F service intersection (very bad) as a result of high delay values usually indicate long cycle times and high vehicle ratios. Solutions that can be obtained are implementing regulations that have been adjusted to the conditions of the intersection, removing side barriers that often occur in each approach, widening the road in one approach and rearranging the cycle time at the intersection
\end{abstract}

\section{Keywords}

Odd-Even Policy, Signalized Intersection, Capacity, Level Of Service

\section{Introduction}

The country of Indonesia is the largest archipelago in the world consisting of 17,504 islands with a total area of 735,335 square miles (Badan Pusat Statistik, 2016). Indonesia has a population of around 270,054,853 million (Central Statistics Agency, 2018) and is the fourth most populous country in the world. With this condition, the government is demanded to be able to provide adequate transportation facilities and infrastructure to connect all regions in this island.

Transportation is an important role in infrastructure development in urban areas.

A good and ideal interaction between transportation components (passengers, goods, facilities, and infrastructure) forms a comprehensive, efficient and effective transportation system. The role of transportation is certainly offset by the active involvement / participation of the parties involved in it. The first party, that is, our users (users) as users must make the maximum contribution to the availability of transportation facilities.

The second party, the operator (operator) is expected to be able to provide services and procurement of transportation facilities optimally. The third party, the regulator, in this case the government as regulator of the transportation system, has the role of giving and issuing policies for users and operators in the transportation system.

Bekasi City is one of the metropolitan cities in the province of West Java, Indonesia with an area of about $210.49 \mathrm{~km} 2$ and a population of 2,873,484 inhabitants (the Central Statistics Agency of the City of Bekasi), which is directly adjacent to several provinces and the Capital City of Jakarta. Because of its location next to the National Capital this provides several advantages in terms of communication and transportation. The ease and completeness of transportation facilities and infrastructure has made the city of Bekasi one of the balancing areas of DKI Jakarta. The city is also part of the Greater Jakarta Metropolitan area and is home to urbanites and industrial centers.

Until now, Bekasi City has not been able to escape from the problem of congestion and until now the points of congestion in the area actually increased. Head of the Bekasi City Transportation Department (Kadishub), Yayan Yuliana, revealed that the factors causing traffic congestion in the high volume of vehicles in the Bekasi area at this time are not comparable to road bodies (Yayan, 2017). 


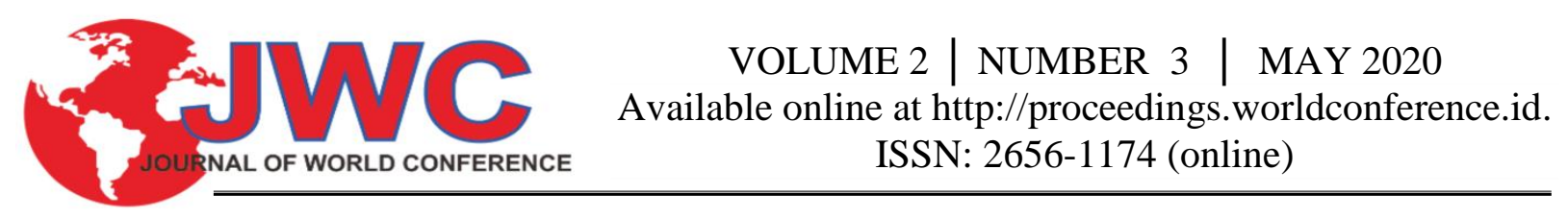

In order to reduce congestion due to the volume of vehicles that pass through the West Bekasi Toll Road that is under construction infrastructure and also overcome the congestion that occurs in the city of Bekasi during rush hour, the Ministry of Transportation (Kemenhub) has applied an odd-even system at the Bekasi Toll Gate since March 12, 2018 The regulations apply Monday - Friday 06.00-09.00 WIB, but do not apply on Saturday Sunday and national holidays. This policy is a vehicle volume restriction that refers to the last number of the corresponding vehicle plate number on the calendar date (odd-even).

Rawa Panjang intersections, JL. Jend. Ahmad Yani, JL. Cut Mutia, JL. Siliwangi is one of the signalized intersections in Bekasi that connects Jakarta and Kerawang. Because of its presence in the city center or CBD (Central Business District) so that it has the potential to cause traffic congestion, especially during rush hour. Apart from that, the traffic lane at the intersection is one of the accesses that are often passed by the community to exit and enter the West Bekasi toll gate, which is the location of even odd regulations which are applied. The road environment around this intersection is a commercial area, with apartments, colleges, shops, and restaurants. There is an undisciplined attitude of public transport drivers who raise and lower passengers carelessly resulting in the intersection of vehicles often queuing especially during rush hour work. Coupled with the number of pedestrians crossing the road between vehicles when the traffic jams. Based on the problems at the intersection four, it is necessary to analyze the characteristics and performance of the Rawa Panjang intersection, JL. Jend. Ahmad Yani, JL. Cut Mutia, JL. Siliwangi.

\section{Methodology}

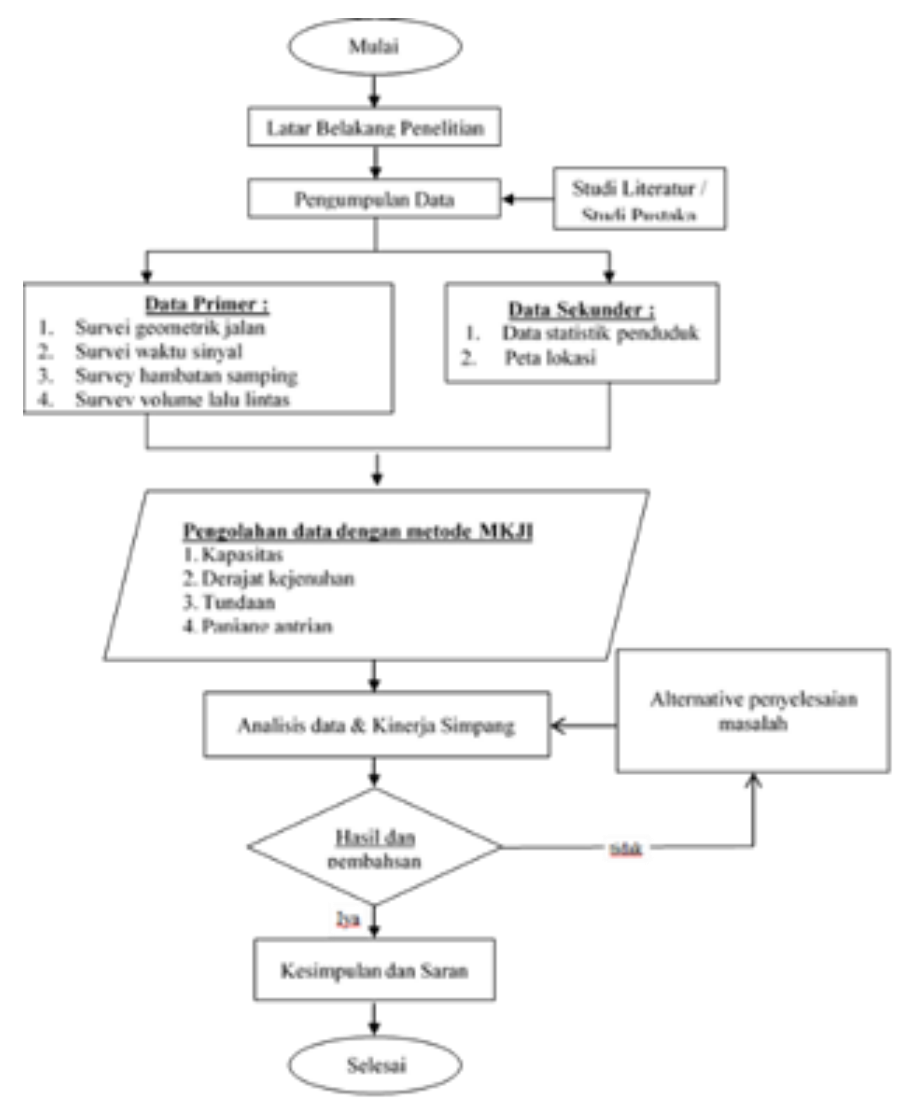

Gambar 2.1 Research Flowchart of the Performance Analysis of the Long Swamp Intersection 


\subsection{LITERATURE REVIEW}

\section{Odd-Even Policies}

In order to optimize the use and movement of traffic on the Jakarta - Cikampek Toll Road during the construction of a national strategic infrastructure project and also to ensure security, safety, order and smoothness of road traffic and transportation, it is necessary to arrange traffic arrangements and restrictions on the operation of freight cars and passenger car. Based on these considerations the Minister of Transportation issued a Regulation of the Minister of Transportation of the Republic of Indonesia Number PM 18 of 2018 concerning traffic regulations with odd-even systems during the construction of the National Strategic Infrastructure project in the Jakarta - cikampek Toll Road Section. In Article 2 in paragraph 1, it is explained that it is effective from 06.00 - WIB until 09.00 WIB.

In Article 4 paragraph 2 the prohibition for each passenger car driver with an odd numbered motorized vehicle crossing the toll road section on an even number date and the prohibition for each passenger car driver with an even numbered motorized vehicle number crossing the toll road section on an odd numbered date. Therefore, for the sake of the implementation of the odd-numbered system, the Department of Transportation carried out various methods for socialization to the public, ranging from banners, road markings, dialogues with car drivers and announcements through the mass media

\section{Intersections}

Intersections are points on a network of intersecting roads and intersecting vehicle trajectories. Intersections are the most important factor in determining the capacity and travel time on a road network, especially for urban areas (DLLAJ, 1987).

The design of the intersection has the main objective of ensuring security for all users, including riders, passengers, pedestrians, bicycle drivers and providing efficient movement of all users through the intersection. (Roger P. Roes, 2004)

\section{Level Of Service}

The level of service (road of service) or road performance is a qualitative measurement that explains the operational conditions in a traffic flow. LOS is related to quantitative measures, such as density or percent time delay. The service level concept was developed for use in the United States and the definition of LOS does not apply directly in Indonesia. In MKJI the speed and degree of saturation are used as indicators of traffic behavior and the same parameters have been used in the development of "traffic engineering guidelines". The following is the level of traffic services at the intersection

Table 2.2 The level of traffic service at the intersection is signaled

\begin{tabular}{cc}
\hline LOS(Levels Of Service) & Tundaan per Kendaraan (det/smp) \\
\hline A & $\leq 5.0$ \\
B & $5.1-15.0$ \\
C & $15.1-25.0$ \\
D & $25.1-40.0$ \\
E & $40.1-60.0$ \\
F & $\geq 60$ \\
\hline
\end{tabular}

(Source Peraturan Menteri Perhubungan No: KM 14 (2006))

\section{Discussion}

\subsection{Traffic Flow Volume}

Traffic volume data used in this thesis research is traffic survey data taken on Monday, Wednesday, Thursday, Saturday or on odd, even, odd, even calendar dates at morning hours (6:00 to 8:00 a.m.), afternoon (18.00-20.00) at the Rawa Panjang intersection. 
Table 3.3 Flow rates of QLT, QST, QRT, Qtotal, on Wednesday morning, even date

\begin{tabular}{|c|c|c|c|c}
$\begin{array}{c}\text { Kode } \\
\text { pendekat }\end{array}$ & $\begin{array}{c}\text { QLT } \\
(\text { smp/jam })\end{array}$ & $\begin{array}{c}\text { QST } \\
(\text { (smp/jam) }\end{array}$ & $\begin{array}{c}\text { QRT } \\
(\text { smp/jam })\end{array}$ & $\begin{array}{c}\text { Qtotal } \\
(\text { smp } / j a m)\end{array}$ \\
\hline S & 743 & 309 & 195 & 1246 \\
\hline U & 237 & 0 & 0 & 237 \\
\hline T & 402 & 1222 & 287 & 1911 \\
\hline B & 289 & 984 & 1147 & 2420
\end{tabular}

(Source : Survey and Analysis Results)

\subsection{Adjustable Saturated Flow}

Saturated Flow (S) is the magnitude of queue departures in an approach during specified conditions (junior high / green hour). The $S$ value can be calculated using the following formula.

$\mathrm{S}=$ So $\mathrm{x}$ FCS $\mathrm{x}$ FSF $\mathrm{x}$ FG $\mathrm{x}$ FRT $\mathrm{x}$ FLT

Table 3.4 Calculation of saturation flow (S) on Wednesday Morning Even Date

\begin{tabular}{c|c|c|c|c|c|c|c|c|}
$\begin{array}{c}\text { Kode } \\
\text { Pendekat }\end{array}$ & So & FCS & FSF & FG & FP & FRT & FLT & $\begin{array}{c}\text { Arus } \\
\text { Jenuh (S) }\end{array}$ \\
\hline Selatan & 5400 & 1 & 0,93 & 1 & 1 & 1,041 & 0,91 & 4727,749 \\
\hline Timur & 7800 & 1 & 0,95 & 1 & 1 & 1,039 & 0,97 & 7440,135 \\
\hline Barat & 6600 & 1 & 0,95 & 1 & 1 & 1,123 & 0,98 & 6907971
\end{tabular}

(Source : Survey and Analysis Results)

Flow Ratio (Flow Ratio) that occurs at each approach in the intersection foot with the same phase, is the ratio between the current (Flow: Q) and saturation current (Saturation flow: S). Current ratio (FR) can be calculated using the formula:

"FR = " "Q" /"S"

Table 3.3 Flow ratio calculation (FR) on Wednesday Morning Even Date

\begin{tabular}{|c|c|c|c|}
\hline $\begin{array}{c}\text { Kode } \\
\text { Pendekat }\end{array}$ & $\begin{array}{c}\text { Arus Lalu } \\
\text { Lintas } \\
(\mathrm{Q}) \\
(\mathrm{smp} / \mathrm{jam})\end{array}$ & $\begin{array}{c}\text { Arus } \\
\text { Jenuh } \\
\text { Lalu } \\
\text { Lintas(S) }\end{array}$ & $\begin{array}{c}\text { Rasio } \\
\text { Arus } \\
(\mathrm{FR})\end{array}$ \\
\hline Selatan & 1246 & 4727,75 & 0,264 \\
\hline Timur & 1911 & 7440,13 & 0,257 \\
\hline Barat & 2420 & 6907,97 & 0,350 \\
\hline
\end{tabular}

(Source : Survey and Analysis Results)

\subsection{Capacity And Degree Of Saturation}

Intersection capacity $(\mathrm{C})$ is the ability of intersections to accommodate maximum traffic flow per unit of time expressed in junior high school / hour. The capacity of the intersections is calculated at each approach or group of lanes in a approach.

"C=S x " "g" /"c"

While the degree of saturation (DS) is the ratio between current (Q) and capacity (C). The following formula degree of saturation.

"DS = " "Q" /"C" 
Table 3.5 Calculation of capacity (C) \& degree of saturation (DS) Wednesday Morning

\begin{tabular}{|c|c|c|c|c|c|c|}
\hline $\begin{array}{c}\text { Kode } \\
\text { Pendekat }\end{array}$ & $\begin{array}{c}\text { Waktu } \\
\text { Hijau } \\
(\mathrm{g}) \\
\text { detik }\end{array}$ & $\begin{array}{c}\text { Waktu } \\
\text { Siklus (c) } \\
\text { detik }\end{array}$ & $\begin{array}{c}\text { Arus } \\
\text { Lalu } \\
\text { Lintas } \\
(\mathrm{Q}) \\
\text { smp jam }\end{array}$ & $\begin{array}{c}\text { Arus } \\
\text { Jenuh } \\
\text { Lalu } \\
\text { Lintas } \\
(\text { S) }\end{array}$ & $\begin{array}{c}\text { Kapasitas } \\
\text { (C) } \\
\text { smp/jam }\end{array}$ & $\begin{array}{c}\text { Derajat } \\
\text { Kejenuhan } \\
\text { (DS) } \\
\text { smp/jam }\end{array}$ \\
\hline Selatan & 30 & 143 & 1246 & 4727,75 & 984,95 & 1,27 \\
\hline Timur & 40 & 143 & 1911 & 7440,13 & 2066,70 & 0,92 \\
\hline Barat & 70 & 143 & 2420 & 6907,97 & 3358,04 & 0,72 \\
\hline
\end{tabular}

(Source : Survey and Analysis Results)

\subsection{Queue Length (QL)}

The number of junior high school queues remaining from the previous green phase (NQ1) and those arriving and stopped in the queue during the red phase (NQ2) can be calculated using the formula: Number of stalled vehicles remaining from the previous green phase:

For DS > 0,5

$$
N Q_{1}=0.25 \times C \times\left[(D S-1)+\sqrt{(D S-1)^{2}+\frac{8 x(D S-0.5)}{C}}\right]
$$

For DS $<0,5$ NQ1 $=0$

Number of vehicles that came and stopped in the queue during the red phase:

$N Q_{2}=c x \frac{1-G R}{1-G R \times D S} \times \frac{Q}{3600}$

Panjang antrian : $N Q=N Q_{1}+N Q_{2}$

Table 3.6 Queue length calculation (QL) Wednesday Morning

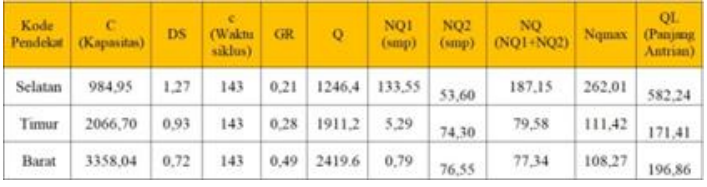

(Source : Survey and Analysis Results)

\subsection{Vehicle Stalled (NS)}

The stop number (NS) in each approach is defined as the average number of vehicles stopped per junior high, including repetitive stops in the queue before crossing the intersection stop line. NS values can be calculated using the formula.

$\mathrm{NS}=0.9 \times \frac{\mathrm{NQ}}{\mathrm{Q} \times \mathrm{c}} \times 3600$

The number of vehicles stopped (NSV) in each approach can be calculated by the formula.

$\mathrm{NSV}=\mathrm{Q} \times \mathrm{NS}(\mathrm{smp} / \mathrm{jam})$

Table 3.7 Vehicle counting stopped (NS) Wednesday morning

\begin{tabular}{|c|c|c|c|c|c|}
\hline $\begin{array}{c}\text { Kode } \\
\text { Pendekat }\end{array}$ & $\begin{array}{c}\mathrm{c} \\
\text { (Waktu } \\
\text { siklus) }\end{array}$ & Q & NQ & NS & NSv \\
\hline Selatan & 143 & 1278.8 & 212.72 & 3.77 & 4819.72 \\
\hline Timur & 143 & 1901.2 & 76.58 & 0.91 & 1735.04 \\
\hline Barat & 143 & 2015.6 & 57.81 & 0.65 & 1309.93 \\
\hline
\end{tabular}

(Source : Survey and Analysis Results) 


\subsection{Delay}

Delay (D) is the additional travel time needed to cross an intersection, compared to an unversity situation. Delay at an intersection is influenced by 2 (two) things, namely:

1) Tundaan lalu lintas (DT)

$$
\mathrm{DT}=(\mathrm{c} \times \mathrm{A})+\left(\frac{\mathrm{NQ} 1 \times 3600}{\mathrm{C}}\right)
$$

Dimana :

$$
\mathrm{A}=\left(\left[\frac{0.5 \times(1-\mathbf{G R})^{2}}{1-(\mathbf{G R} \times \mathbf{D S})}\right]\right)
$$

2) Tundaan geometrik rata-rata pada suatu pendekat (DG)

$\mathrm{DG}=\{(1-\mathrm{Psv}) \times(\mathrm{Pt} \times 6)\}+($ Psv $\mathrm{x} 4)$

3) Untuk menghitung tundaan pada Simpang $\mathrm{D}=\mathrm{DT}+\mathrm{DG}$

Table 3.8 Calculation of delay (DT) \& (DG) Wednesday Morning

\begin{tabular}{|c|c|c|c|c|c|c|c|c|c|c|}
\hline $\begin{array}{c}\text { Kode } \\
\text { Pendekat }\end{array}$ & $\begin{array}{c}\text { c } \\
\text { (Waktu } \\
\text { siklus) }\end{array}$ & $\begin{array}{c}\text { NQ1 } \\
\text { (smp) }\end{array}$ & GR & DS & A & $\begin{array}{c}\text { C } \\
\text { (Kapasit } \\
\text { as) }\end{array}$ & $\begin{array}{c}\text { PSV } \\
\text { Nstotal }\end{array}$ & DT & PT = Prt & DGj \\
\hline Selatan & 143 & 157.22 & 0.21 & 1.32 & 0.43 & 969.41 & 1.51 & 645.60 & 0.11 & 5.73 \\
\hline Timur & 143 & 3.87 & 0.28 & 0.90 & 0.35 & 2111.75 & 1.51 & 56.18 & 0.15 & 5.58 \\
\hline Barat & 143 & 0.23 & 0.49 & 0.59 & 0.18 & 3399.29 & 1.51 & 26.49 & 0.50 & 4.51 \\
\hline
\end{tabular}

(Source : Survey and Analysis Results)

Table 3.9 Calculation of average delay (DI) Wednesday Morning

\begin{tabular}{|c|c|c|c|c|r|}
\hline $\begin{array}{c}\text { Kode } \\
\text { Pendekat }\end{array}$ & Q & DT & DGj & D & DxQ \\
\hline Selatan & 1278.80 & 645.60 & 5.73 & 651.32 & 832,914 \\
\hline Timur & 1901.20 & 56.18 & 5.58 & 61.76 & 117,422 \\
\hline Barat & 2015.60 & 26.49 & 4.51 & 31.00 & 62,484 \\
\hline Total & 1611.60 & & & & 9,670 \\
\hline
\end{tabular}

(Source : Survey and Analysis Results)

\subsection{Level Of Intersection Service}

Based on the average delay value of each approach, the level of service at each approach can be determined. In this study the delay value was taken based on the results of the field survey and analysis. The following table results from the level of service at the intersection.

Table 3.10 Calculation of the service level at the Wednesday morning intersection

\begin{tabular}{|l|c|c|c|c|}
\hline \multicolumn{5}{|c|}{ Kinerja Simpang Bersinyal } \\
\hline Pendekat & Timur & Utara & Selatan & Barat \\
\hline Waktu Hijau det (g) & 40 & & 30 & 70 \\
\hline $\begin{array}{l}\text { Arus Lalu Lintas smp/jam } \\
\text { Q) }\end{array}$ & 1901.2 & 276 & 1278.8 & 2015.6 \\
\hline Kapasitas = C & 2111.75 & & 969.41 & 3399.29 \\
\hline $\begin{array}{l}\text { Derajat Kejenuhan } \\
\text { DS = Q/C }\end{array}$ & 0.90 & & 0.90 & 0.59 \\
\hline Rasio Hijau GR = g/c & 0.28 & & 0.21 & 0.49 \\
\hline $\begin{array}{l}\text { Kendaraan antri } \\
\text { NQ1+NQ2=NQ }\end{array}$ & 76.58 & & 212.72 & 57.81 \\
\hline Panjang Antrian (QL) & 164.94 & & 661.80 & 147.17 \\
\hline Angka Henti (NS) & 0.91 & & 3.77 & 0.65 \\
\hline Jml kend terhenti (Nsv) & $1,735.04$ & & $4,819.72$ & $1,309.93$ \\
\hline $\begin{array}{l}\text { Tundaan rata-rata } \\
\text { D=DT+DG }\end{array}$ & 61.76 & \multicolumn{5}{|c|}{194.938} & 31.00 \\
\hline $\begin{array}{l}\text { Tundaan Total DxQ } \\
\text { smp/det) }\end{array}$ & \multicolumn{5}{|c|}{ F } \\
\hline LOS & \multicolumn{5}{|c|}{} \\
\hline
\end{tabular}

(Source : Survey and Analysis Results) 


\subsection{Kondisi Ruas jalan Jend. Ahmad Yani}

Kondisi geometrik dan fasilitas Jl. Jend Ahmad Yani adalah sebagai berikut :

- Tipe Jalan : $\quad 4 / 2 \mathrm{D}$

- Lebar Jalur $\quad: 11 \mathrm{~m}$

- Lebar trotoar : $1 \mathrm{~m}$

- Tipe Alinyemen : Datar

- Marka Jalan : Ada

- Rambu Lalu Lintas: Ada

- Jenis Perkerasan : Aspal Beton

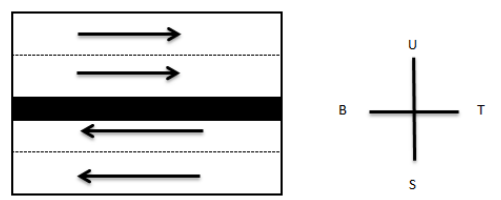

Gambar 3.2 Street Sketches Jend. Ahmad Yani

\subsection{Road Traffic Volume Data}

Traffic data is obtained through surveys taken at representative hours which are considered at that hour as the quantity of traffic flow from the road increases. The traffic data collection survey was conducted for 4 days as a representative in order to obtain the volume of Jalan Jend. Ahmad Yani. To determine the EMP of each type of vehicle

Table 3.11 Observation of Traffic Volume of Roads Jend. Ahmad Yani

\begin{tabular}{|c|c|c|c|c|c|c|c|c|}
\hline Pagi & \multicolumn{3}{|c|}{ Kendaraan } & \multirow{2}{*}{$\begin{array}{c}\text { Total } \\
\text { Kend/Jam }\end{array}$} & \multicolumn{3}{|c|}{ smp } & \multirow{2}{*}{$\begin{array}{c}\text { Total } \\
\text { smp/Jam }\end{array}$} \\
\hline Jam & HV & LV & MC & & \multicolumn{3}{|c|}{ LV } & \\
\hline $07.00-08.00$ & 224 & 880 & 3292 & 4396 & $\frac{1.2}{268.8}$ & $\frac{1}{880}$ & $\frac{0.35}{11522}$ & 2301 \\
\hline & & & & & & & & \\
\hline Sore & \multicolumn{3}{|c|}{ Kendaraan } & & \multicolumn{3}{|c|}{ smp } & \\
\hline Jam & HV & LV & MC & Kend/Jam & HV & LV & MC & smp/Jam \\
\hline $17.00-18.00$ & 212 & 720 & 1960 & 2892 & 254.4 & 720 & 686 & 1660.4 \\
\hline & & & & & & & & \\
\hline
\end{tabular}

(Source : Survey and Analysis Results)

\subsection{Speed Of Survey Results Of Roads}

To get actual vehicle speed data, from the survey results three light vehicle samples were taken during rush hour ie morning and evening, by calculating the speed at the specified distance $(100 \mathrm{~m})$. The complete results are shown as the table below.

Table 3.12 Road Speed Observation Data Jend. Ahmad Yani

\begin{tabular}{|c|c|c|c|c|c|c|c|}
\hline Pagi & \multicolumn{3}{|c|}{ Waktu Tempuh Kend (det) } & \multirow{2}{*}{$\begin{array}{r}\text { Jarak } \\
(\mathrm{km})\end{array}$} & \multicolumn{2}{|c|}{$\begin{array}{c}\text { Waktu Tempuh Rata } \\
\text { rata }\end{array}$} & \multirow{2}{*}{$\begin{array}{c}\mathrm{Kec} \\
(\mathrm{km} / \mathrm{jam})\end{array}$} \\
\hline Jam & 1 & 2 & 3 & & (det) & (jam) & \\
\hline \begin{tabular}{|l|}
$07.00-08.00$ \\
\end{tabular} & 16 & 15 & 15 & 0.1 & 15 & 0.004259 & 23.47826 \\
\hline Sore & \multicolumn{3}{|c|}{ Waktu Tempuh Kend (det) } & Jarak & \multicolumn{2}{|c|}{ Waktu Tempuh Rata } & $\mathrm{Kec}$ \\
\hline & 1 & 2 & 3 & $(\mathrm{~km})$ & (det) & (jam) & $(\mathrm{km} / \mathrm{jam})$ \\
\hline $17.00-18.00$ & 18 & 16 & 15 & 0.1 & 16.333333 & 0.004537 & 22.04082 \\
\hline & & & & & & & \\
\hline
\end{tabular}

(Source : Survey and Analysis Results)

\subsection{Road Section Capacity}

Calculation of road segment capacity is carried out using MKJI 1997 for urban areas as follows: $\mathrm{C}=\mathrm{CO} \times \mathrm{FCW} \times \mathrm{FCSP} \times \mathrm{FCSF} \times \mathrm{FCCS}$

Based on data on geometric conditions and road environmental conditions at peak hours for example data analysis, has the characteristics or adjustment factors as described below:

Direction West Bekasi Toll Gate - Jalan Jend. Ahmad Yani : 
a. $\quad \mathrm{CO} \rightarrow$ Tipe jalan terbagi $\rightarrow$ Kapasitas dasar (1650/lajur) Terdapat 2 lajur $=2 \times 1650=3300$ smp/jam

b. FCW $\rightarrow$ Tipe jalan (jalan tak terbagi) $\rightarrow$ Lebar lajur 3,50 $\mathrm{m}$ Faktor penyesuaian lebar lajur $=1,03$

c. $\quad$ FCSP $\rightarrow$ Untuk jalan terbagi $=1$

d. $\quad$ FCSF $\rightarrow$ Kelas hambatan samping $\rightarrow$ Rendah $(\mathrm{R})$ Faktor penyesuain hambatan samping $=0.94$

e. $\quad$ FCCS $\rightarrow$ jumlah jiwa $\rightarrow 1$ jt -3 jt $=1,00$

f. With the above calculation, overall capacity $(\mathrm{C})$ can be shown in the table below.

Table 3.13 Road Capacity (C) Jend. Ahmad Yani

\begin{tabular}{|c|c|c|c|c|c|c|}
\hline Pagi & \multicolumn{5}{|c|}{ Faktor Penyesuaian Untuk Kapasitas } & \multirow{2}{*}{$\begin{array}{c}\text { Kapasitas (C) } \\
(\mathrm{smp} / \mathrm{jam})\end{array}$} \\
\hline Jam & Co & $\mathrm{FCw}$ & FCsp & FCsf & FCcs & \\
\hline $07.00-08.00$ & 3300 & 1.03 & 1.00 & 0.94 & 1.00 & 3195.06 \\
\hline & \multirow{2}{*}{\multicolumn{5}{|c|}{ Faktor Penyesuaian Untuk Kapasitas }} & \\
\hline Sore & & & & & & Kapasitas (C) \\
\hline \begin{tabular}{|l|} 
Jam \\
\end{tabular} & Co & $\mathrm{FCw}$ & FCsp & FCsf & FCes & (smp/jam) \\
\hline $17.00-18.00$ & 3300 & 1.03 & 1.00 & 0.94 & 1.00 & 3195.06 \\
\hline
\end{tabular}

(Source : Survey and Analysis Results)

\subsection{The Degree Of Saturation Of Road Sections}

According to the $1997 \mathrm{MKJI}$, the degree of saturation (DS) is defined as the ratio of road current to capacity, which is used as a major factor in determining the level of performance of intersections and road segments. DS value indicates whether the road segment has a capacity problem or not. The basic equation for determining the degree of saturation is as follows:

$$
\mathrm{DS}=\frac{\mathrm{Q}}{\mathrm{C}}
$$

With the formula above, overall capacity (DS) can be shown in the table below.

Table 3.14 Degree of Saturation (DS) Road Section Jend. Ahmad Yani

\begin{tabular}{|c|c|c|c|c|}
\hline Pagi & $\begin{array}{c}\text { Vol. lalu } \\
\text { lintas (Q) }\end{array}$ & $\begin{array}{c}\text { Kapasitas } \\
\text { Jalan (c) }\end{array}$ & $\begin{array}{c}\text { Derajat } \\
\text { Kejenuhan }\end{array}$ & \multirow{2}{*}{ LOS } \\
\hline Jam & (smp/jam) & $($ smp/jam) & Q/C & \\
\hline $07.00-08.00$ & 2301 & 3195.06 & 0.720 & D \\
\hline & & & & \\
\hline Sore & $\begin{array}{c}\text { Vol. lalu } \\
\text { lintas (Q) }\end{array}$ & $\begin{array}{c}\text { Kapasitas } \\
\text { Jalan (c) }\end{array}$ & $\begin{array}{c}\text { Derajat } \\
\text { Kejenuhan }\end{array}$ & \multirow{2}{*}{ LOS } \\
\cline { 1 - 3 } Jam & (smp/jam) & (smp/jam) & Q/C & \\
\hline $17.00-18.00$ & 1660.4 & 3195.06 & 0.520 & C \\
\hline & & & & \\
\hline
\end{tabular}

(Source : Survey and Analysis Results)

\subsection{Free Current Speed}

Free flow speed uses light vehicles as the main measure of performance. According to the MKJI 1997, the equation for determining the free flow velocity has the following general form:

$\mathrm{FV}=(\mathrm{FVO}+\mathrm{FVW}) . \mathrm{FFVSF} . \mathrm{FFVCS}$

Jalan Komjen Pol. M Jasmin towards UI - Jalan Komjen Pol. M Jasmin as an example of data analysis, has the characteristics or adjustment factors as described below:

a) $\quad$ FVO $\rightarrow$ Tipe jalan $(4 / 2 \mathrm{D}) \rightarrow$ Kecepatan arus bebas dasar $=69$

1) Kendaraan Ringan (LV) = $78 \mathrm{~km} / \mathrm{jam}$

2) Kendaraan Berat (HV) = $65 \mathrm{~km} / \mathrm{jam}$

3) Sepeda Motor $(\mathrm{MC})=64 \mathrm{~km} / \mathrm{jam}$

4) Semua Kendaraan (rata-rata) $=69 \mathrm{~km} / \mathrm{jam}$

b) FVW $\rightarrow$ Tipe jalan (jalan tak terbagi) $\rightarrow$ Lebar lajur $5 \mathrm{~m}=2$

c) FFVSF $\rightarrow$ Kelas hambatan samping $\rightarrow$ Rendah $(\mathrm{R})=0,96$

Based on the type of road, a four-lane two-way road divided by a shoulder $<0.5 \mathrm{~m}$, the road segment is a side obstacle class with high frequency, so from Table B-3: 1 Chapter 5 Urban Road Manual Indonesian Road Capacity 1997 obtained a free flow adjustment factor for side barriers 
d) FFVCS $\rightarrow$ The population of Bekasi City1.803.708 jiwa $\rightarrow 1 \mathrm{jt}-3 \mathrm{jt}=1,00$

Due to the location of Jalan Jend. Ahmad Yani is included in the area of Bekasi city with a population of more than 1-3 million people

Then the FV value can be known by calculation as follows in the table below.

Table 3.15 Free Flow Speed Calculation for Roads Jend. Ahmad Yani

\begin{tabular}{|c|c|c|c|c|c|c|}
\hline Pagi & \multicolumn{4}{|c|}{ Faktor Penyesuaian Untuk Kapasitas } & \multirow{2}{*}{$\frac{\text { Kec. Arus Bebas (FV }}{\mathrm{km} / \mathrm{jam}}$} & \multirow{2}{*}{ 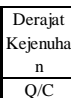 } \\
\hline Jam & Fvo & $\mathrm{FVw}$ & FFVsf & FFV cs & & \\
\hline $07.00-08.00$ & 69 & 2 & 0.960 & 1 & 68.16 & 0.720 \\
\hline Sore & & enyes & Untuk $\mathrm{K}$ & asitas & Kec, Arus Bebas_FY & $\begin{array}{l}\text { Derajat } \\
\text { Kejenuha }\end{array}$ \\
\hline Jam & Fvo & $\mathrm{FVW}$ & FFVsf & FFV & $\mathrm{km} / \mathrm{jam}$ & $\mathrm{Q} / \mathrm{C}$ \\
\hline $17.00-18.00$ & 69 & 2 & 0.960 & 1 & 68.16 & 0.520 \\
\hline
\end{tabular}

(Source : Survey and Analysis Results)

\subsection{Service Levels Of Roads}

From the results of the analysis with the Indonesian Road Capacity Manual Method (MKJI) 1997, Jalan Jend. Ahmad Yani has a degree of saturation of DS $=0.72$, the level of service is at the level of service D. After all values are obtained by calculation, the results of all calculations are made in a table to make it easier to analyze the final results.

Table 3.146 Service Levels for Roads Jend. Ahmad Yani

\begin{tabular}{|c|c|c|c|c|c|c|}
\hline Pagi & $\begin{array}{c}\text { Vol. lalu } \\
\text { lintas (Q) }\end{array}$ & $\begin{array}{c}\text { Kapasitas } \\
(\mathrm{C})\end{array}$ & $\begin{array}{c}\text { Kec. Arus } \\
\text { Bebas } \\
(\mathrm{FV})\end{array}$ & $\begin{array}{c}\text { Derajat } \\
\text { Kejenuhan }\end{array}$ & FVLV & LOS \\
\hline Jam & (smp/jam) & $(\mathrm{smp} / \mathrm{jam})$ & $\mathrm{km} / \mathrm{jam}$ & $\mathrm{Q} / \mathrm{C}$ & $\mathrm{km} / \mathrm{jam}$ & \\
\hline $07.00-08.00$ & 2301 & 3195.06 & 68.16 & 0.720 & 53.5 & $\mathrm{D}$ \\
\hline & & & & & & \\
\hline Sore & $\begin{array}{c}\text { Vol. lalu } \\
\text { lintas (Q) }\end{array}$ & $\begin{array}{c}\text { Kapasitas } \\
(\mathrm{C})\end{array}$ & $\begin{array}{c}\text { Kec. Arus } \\
\text { Bebas } \\
\text { (FV) }\end{array}$ & $\begin{array}{c}\text { Derajat } \\
\text { Kejenuhan }\end{array}$ & FVLv & LOS \\
\hline Jam & (smp/jam) & (smp/jam) & $\mathrm{km} / \mathrm{jam}$ & Q/C & $\mathrm{km} / \mathrm{jam}$ & \\
\hline $17.00-18.00$ & 1660.4 & 3195.06 & 68.160 & 0.520 & 51 & $\mathrm{C}$ \\
\hline & & & & & & \\
\hline
\end{tabular}

(Source : Survey and Analysis Results)

\section{Conclussion}

After conducting research on the analysis of the performance of the Rawa Panjang signal-related intersections and intersections related to the Odd-Even policy at the West Bekasi Toll gate, what can be summarized as follows:

\subsection{Intersection Performance}

1) The results of the analysis calculated in this study only carry out the calculation analysis at the Rawa Panjang intersection. Related intersections around the Rawa Panjang intersection are not included in the calculation.

2) The highest traffic volume occurred on Wednesday 20 November 2019 at 06.00-08.00 at $5814 \mathrm{pcu} /$ hour, with a capacity value (C) of $6409.69 \mathrm{pcu} /$ hour. So that the degree of saturation (DS) can be obtained at 0.87 with a queue length $(\mathrm{QL})$ that occurs on the south side of 582.24 meters, on the east side 171.41 meters, on the west side 196.86 meters. With the value of the delay (D) the intersection of 654.10 seconds / junior high

3) The performance of the Bekasi Rawa Panjang signal intersection at the maximum current (and in the hours of the policy of Odd-Even Even West Bekasi Toll Gate) has a Level Of Service (LOS) or level of intersection service with a value of $\mathrm{F}$ (very bad). So that the enactment of the Odd-Even policy at the West Bekasi Toll gate does not affect the performance of the intersections around it, especially the Rawa Panjang Signalized Intersection. 
4) The results of the analysis of alternative solutions by adjusting the cycle time and delivery time of heavy vehicles (HV) show the degree of saturation has changed from the previous condition and the average deviation delay value is $33.41 \mathrm{pcu} / \mathrm{sec}$. Then, obtained the level of intersection services namely LOS D

\subsection{Quick Performance}

1) The results of the analysis calculated in this study only performed a calculation analysis on the Ahmad Yani Road Section heading towards the West Bekasi Toll Gate.

2) Performance of Jalan Jend. Ahmad Yani of Bekasi City at the maximum current (and in the hours when the Odd-Even Policy of the West Bekasi Toll Gate) has a Level Of Service (LOS) or the level of service of roads with a $\mathrm{D}$ value in the morning and $\mathrm{C}$ value at night. Traffic volume $(\mathrm{Q})$ in the morning is 2301 $\mathrm{pcu} /$ hour and at night is $1660.4 \mathrm{pcu} /$ hour. And the speed of free flow (FV) for the morning and evening is $68.16 \mathrm{~km} /$ hour.

\subsection{Suggestion}

From the results of this analysis, the authors have suggestions that can be considered for application to the Bekasi City Rawa Panjang Intersection among other things as follows:

1) There needs to be a clock adjustment for Large or Heavy vehicles crossing the intersection, so as not to cross at peak times or rush hours

2) Controlling public transportation on the east side of the east turn left langung, which often waits for passengers which causes long queues for the flow that passes through the road to turn left or straight

3) Closing of the turning direction which is on the east approach in front of the Perbanas Institute Campus which often causes queues, can be diverted to turn back on the area under the bridge of the Bina Sarana Informatics campus.

4) Installation of signs is prohibited from turning back at each of the front ends of the approach, because with frequent or the number of vehicles that turn around at the ends of each approach causes a delay that finally occurs anntrian length of the vehicle

\section{References}

Ahmad Munawar, (2009), Analsis Arus Jenuh Dan Panjang Antrian Pada Simpang Bersinyal Studi Kasus Di Jalan Dr.Sutomo SuryopranotoYogyakarta.

Arief, (2016), Analsis Kinerja Simpang Bersinyal Pada Simpang Ciruas Kota Serang.

Badan Pusat Statistik. (2018).

Chodur. J, Ostrowski. K, Tracz. M, (2016), Variability of Capacity and Traffic Performance at Urban and Rural Signalised Intersection.

Departemen Pendidikan dan Kebudayaan. (1995). Kamus Besar Bahasa Indonesia

Dewinta Marta, (2017), Analisis Kinerja Simpang Bersinyal Jalan Joglo Raya Jakarta Barat,Universitas Merucbuana

Abbas. Direktorat Jenderal Bina Marga (DJBM), (1997),. "Manual Kapasitas Jalan Indonesia", Departemen Pekerjaan Umum, Jakarta

Transportation Donny, (2019), Kajian Analisis Lalulintas Simpang Bersinyal Di By Pass Krian Untuk Perencanaan Pelebaran Jalan Dan Fly Over

Dwi Anita, (2015), Evaluasi Kinerja Simpang Bersinyal Jalan 17 Agustus-Jalan Babe Palar Kota Manado

Dwi Esti, (2016), Analsis Kinerja Simpang Bersinyal Pada Simpang Boru- Serang

Eko Nugroho, (2012), Optimalisasi Kinerja Simpang Bersinyal Bangkong Semarang

Elsafan, (2018), Perhitungan Kinerja Simpang BersinyalMenggunakanMetode MKJI (1997) Dan Perangkat Lunak PTV Vistro Surakarta

Ganang, (2015), Analisis Kemacetan Pada Simpang Jawa Di Kota Madiun

Gland, (2013), Kinerja Lalu Lintas Persimpangan Lengan Empat Bersignal (Studi Kasus Persimpangan Jalan Walanda Maramis Manado)

Kumar. R. N, Dr. M. S. Nagakumar, (2014), Performance Evaliation Of At Grade Intersection and Improvement Using Signal Coordination.

Liputan6.com. (2018). Prediksi Wali Kota Bekasi, Jalan Di Bekasi ini Bakal Macet sampai (2023), Bekasi. 
Meliyana, (2015), Analisis Kinerja Simpang Bersinyal Berlengan Empat (Studi Kasus Simpang Surabaya) Banda Aceh

Peraturan Menteri Perhubungan Republik Indonesia Nomor PM 18 Tahun (2018).Pengaturan Lalu Lintas Selama Masa Pembangunan Proyek Infrastruktur Strategis Nasiaonal Di Ruas Jalan Tol Jakarta - Cikampek.

Peraturan Pemerintah Republik Indonesia Nomor 34 Tahun (2006). Jalan

Pignataro, L. J., (1973). Trafic Engineering Theory and Practice. Premtice - Hall, Inc.,New Jersey, USA.

Rizal, (2019), Kinerja Simpang Bersinyal Jalan Ahmad Yani Dengan Jalan M. Hasibuan - Jalan KH. Noer Ali Kota Bekasi

Roger. P.R. Elena S.P. William. R. M, (2004). Trafic Engineering Third Edition. Preason Prentice Hall, New Jersey, USA.

Tracz. M, Chodur. J, (2012), Performance and Safety of Roundouts with Traffic Signals.

\section{Biography}

Widodo Budi Dermawan is a Practitioner as well as a Lecturer in Civil Engineering, especially in the field of Transportation, he took Strata 1 at Parahyangan Catholic University (1994), and took his Masters at the University of Wisconsin-Madison (1996). In the work of education, he teaches at Mercu Buana University (Meruya), University of Indonesia (Depok), etc.

Ahmad Chalimin is a student at Mercu Buana University. With work experience, namely in PT Truba Jurong Engineering is engaget Contractor, PT Citra Megah Gemilang, PT United Engineering Indonesia is engaged in Contractor \& other contractor in the specialist field of PLTU. 